\title{
Web-based Tutorials and Traditional Face-to-Face Lectures: A Comparative Analysis of Student Performance
}

\author{
Retta Guy \& Millicent Lownes-Jackson \\ Tennessee State University, Nashville, Tennessee, USA
}

rguy@tnstate.edu mlownes@tnstate.edu

\begin{abstract}
The authors present the results of a study conducted at a historically Black institution that compares student performance using Web-based tutorials to that of the traditional face-to-face lectures. A casual-comparative design was chosen for this study to examine the effects of instructional delivery on student performance in a business communications course with specific emphasis on the grammar and mechanics unit of study. The study spanned 4 years, beginning fall 2008 through spring 2012. Participants included 375 declared business majors who were self-enrolled in various sections of the Business Communications course during the study. The results of this study mirrored those of previous works reporting that Web-based tutorials are as effective as traditional face-to-face lecturing with regard to student performance.
\end{abstract}

Keywords: Web-based tutorials, interactive tutorials, grammar and mechanics, tutorials, student performance, face-to-face lectures

\section{Introduction}

The advent of computers and information technology has made major inroads into university teaching, with Web- and computer-based tutorials now being considered as acceptable and effective methods of learning.

As university faculty and administrators continue examining tools and methods to support and engage students, face-to-face lecture is still the main and time-honored means of disseminating knowledge (Sweeney, O'Donoghue, and Whitehead, 2004). However, the evolution of the Web from merely a text-based medium to one that incorporates visual representation, animation, and user-manipulable materials (Donovan and Nakhleh, 2007), has caused an alarming number of educators to consider the use of Web-based tutorials as an alternative to the traditional face-toface lecture style delivery of education (Cheng and Swanson, 2011; Sweeney, et al., 2004; Gremler, et al., 2000).

Material published as part of this publication, either on-line or in print, is copyrighted by the Informing Science Institute. Permission to make digital or paper copy of part or all of these works for personal or classroom use is granted without fee provided that the copies are not made or distributed for profit or commercial advantage AND that copies 1) bear this notice in full and 2) give the full citation on the first page. It is permissible to abstract these works so long as credit is given. To copy in all other cases or to republish or to post on a server or to redistribute to lists requires specific permission and payment of a fee. Contact Publisher@InformingScience.org to request redistribution permission.
A Web-based tutorial can be described as a combination of media (audio, video, animation, PowerPoint slides) that allows the user to control, combine, and manipulate different types of mediums of communication such as text, graphics, still images, and interactive features (Moallem, 2008; Zhang, 2004). According to education theorists, Webbased tutorials that incorporate interactivity in the form of learners' control, 
feedback, and hyperlinked information can enhance academic performance by allowing students to actively experiment with concepts on their own and outside the classroom (Lee, Courtney, and Balassi, 2010; Barnes, Scutter, and Young, 2005) and by allowing students to determine their own path through the material as reflective of a distributed interactive learning environment (Khalifa and Lam, 2002; DeBord, et al., 2004). Moreover, Haseman, Nuipolatoglu, and Ramamurthy (2002) and Singh and Haileselassie (2010) further suggests that successful interactive Web-based tutorials should use examples, practice, feedback, self-pacing, user control, and questions in order to achieve positive learner outcomes.

During the early development stages of tutorials, educators and researchers alike argued that while lecture provides content to making learning possible, the Web-based tutorial is the major avenue to activate the learning process (Dawson, 1998). In 2001, Greenhagh noted that many university faculty and administrators believe that Web-based tutorials have several advantages over lectures, such as:

- they foster a more flexible learning program;

- they are designed with the capability to pause or revisit areas of the session;

- they facilitate more student-led interactions;

- they support hyperlinks and additional materials that are provided instantly for the student;

- they address the issue of standardizing the quality of teaching materials across a region; and

- they deal with the cost and logistical difficulties of lecturers teaching large numbers of students in different locations.

Proponents of innovative mediated and multimedia learning assert that Web-based tutorials offer opportunities to increase student engagement and understanding of material (Cheng and Swanson, 2011; Cheng, 2010; Sandman, 2009) and that the use of such frameworks "cultivates an active and multi-sensory learning environment to better address student auditory, visual, and kinesthetic learning styles" (Chen and Swanson, 2011, p. 16).

On the other hand, Bonham, Deardorff, and Beichner (2003) cite potential drawbacks of Webbased tutorials that include a lack of detailed feedback, a feeling of social isolation, impersonalization by replacing an instructor with the computer, along with the potential for technical difficulties (Margolis, Grediagin, Koenig, and Sanders, 2009). Opponents also have expressed concern that Web-based tutorials could potentially reduce interpersonal skills and discourage creativity (Oppenheimer, 2003). Moreover, Bonham and colleagues contend that from a pedagogical standpoint, Web-based tutorials offer a tradeoff between limited but immediate feedback and more complete but delayed feedback.

\section{Study Purpose}

It is perhaps a forgone conclusion that in the future college students will do the majority of learning using computers and the World Wide Web; therefore, it is important to build upon evidence for teaching and learning through the use of such tools and medium. As stated by Sweeney and colleagues (2004), "the need for such research has been amplified in recent times by the perceived need for universities to use the Internet and the WWW as part of the shift to flexible learning" (p. 312).

While there have been trials examining students' perception of and attitude toward Web-based interventions, much more research needs to be undertaken on student performance. Hence, the 
purpose of the current study was to explore whether there is a significant difference between the academic performance of students who participated in a traditional lecture style unit of study on grammar and mechanics in a business communications course and the academic performance of students using a comparable Web-based tutorial. Thus the following hypotheses are proposed:

H1: There is a significant difference in pre-test grades between students using Webbased tutorials and those who attended face-to-face lectures.

Null: There is no significant difference in pre-test grades between students using Webbased tutorials and those who attended face-to-face lectures.

H2: There is a significant difference in post-test mid-term grades between students using Web-based tutorials and those who attended face-to-face lectures.

Null: There is no significant difference in post-test mid-term grades between students using Web-based tutorials and those who attended face-to-face lectures.

H3: There is a significant difference in post-test final grades between students using Web-based tutorials and those who attended face-to-face lectures.

Null: There is no significant difference in post-test final grades between students using Web-based tutorials and those who attended face-to-face lectures.

It is important to note that this study builds upon earlier research conducted by the authors that assessed the effectiveness of Web-based tutorials using pre- and post-test measurements (Guy and Lownes-Jackson, 2012).

\section{Literature Review}

While the popularity and acceptance of Web-based tutorials are undeniable, researchers are focused on whether it actually supports the learning process (Sweeney and Ingram, 2001). A review of literature reports on a number of primary research studies that have provided comparable data on measureable performance relative to the use of Web-based tutorial versus face-to-face lecture.

\section{Greater Student Performance with Web-Based Tutorials}

Early study results described herein illustrate greater student performance with the use of Webbased tutorials when compared to traditional face-to-face lectures. For instance, Alavi (1994) compared the performance of a group of MBA students who used Web-based learning exercises to those who did not, with lecture designated as the primary method of instruction for the subsequent group. Students' affective reactions to the Web-based learning exercises were positive and their final course grades were also significantly higher compared to those students who were not exposed to the Web-based mediated environment.

Beerman (1996) hypothesized that students whose lectures were augmented with the Web-based tutorial would outperform those in the lecture-based sections only. Beerman compared test scores and final grade distributions in an introductory nutritional science course whereby students were taught with traditional lectures over two years followed by another two years of instruction in which students received lecture combined with the Web-based tutorial. The results revealed that students taught with the Web-based tutorial had significantly higher test scores.

Similarly, Schutte (1996) conducted a randomized controlled study comparing student performance of 33 sociology majors in a junior-level course. The students were divided into two groups. Group one received instruction through lecture whereas group two reviewed Web-based tutorials. Both groups learned the same content with similar activities and problem-based assign- 
ments. The results revealed that the students in the Web-based group outperformed their peers in the classroom environment on both the mid-term and final examinations.

Koch and Gobell (1999) found that Web-based tutorials led to improved accuracy in decisions about design and the correct choice of statistics in an advanced course on research methods and statistics. Likewise, Maki and Maki (2000) found that the use of Web-based multimedia tutorials resulted in higher learning gains when compared to face-to-face lectures, with equal results found in 2003 whereby students in the Web-based version of the course did slightly better than students in the lecture version.

Andrewartha and Wilmont (2001) conducted a pilot study involving two non-random groups of volunteer media arts students. Twelve students studied the course using Web-based multimedia tutorials whereas 20 students studied the course in a traditional classroom environment. Both groups received a pre-test on the subject and a post-test after completing the study. Students in the Web-based multimedia tutorial group had a pre-test score of $25 \%$ and a post-test score of $62 \%$ compared to the classroom group with a pre-test score of $24 \%$ and a post-test score of $38 \%$. The Web-based multimedia tutorial group improved by a significant margin; hence, the authors agreed that the Web-based tutorial was as good as traditional classroom instruction.

In a series of 5 experiments, over 600 students at 2 different universities with 3 different professors, Scheines, Leinhardt, Smith, and Cho (2005) compared student performance in a semesterlong course on causal and statistical reasoning. The researchers compared pre- and post-test gains of students in traditional lecture and Web-based formats. The final analysis verified that students who entirely replaced going to lecture with doing Web-based modules did as well and usually better than those who went to lecture.

More recently, Donovan and Nakhleh (2007) used Web-based tutorials and the traditional faceto-face lecture series to compare student performance in a general chemistry class. In the final analysis, students who used the Web-based tutorial demonstrated a deeper level of understanding of chemistry compared to those exposed only to the lecture series. Likewise, Bartini (2008) compared student performance in a 200 -level child psychology class by providing instruction in a traditional lecture format versus the use of Web-based instructional materials and tutorials. In comparison, the students in the Web enhanced section earned higher exam scores.

Osborn (2010) conducted a study that included 325 students enrolled in an introductory psychology class at a small, historically Catholic liberal arts college in the South. While all study participants received face-to-face lectures, the experimental group received supplemental instruction through Web-based tutorials and the control group received print-based supplemental material. The results indicated that students in the experimental group outperformed those in the control group for which the researcher attributes to the provision of instantaneous, targeted and detailed feedback driven by the Web-based tutorial.

To assess how the use of Web-based tutorials affect student learning, Cheng and Swanson (2011) conducted a quasi-experiment in which 78 participants were assigned to two groups. Students in the control group received text-based lectures whereas those in the treatment group were provided with Web-based learning modules. The findings revealed that the treatment group with access to Web-based tutorials outperformed those in the control group with lectures.

Sargent, Borthick, and Lederbert (2011) examined the impact of Web-based tutorials on student performance. Study participants included 426 students enrolled in two lecture classes of Principles of Accounting II at a large urban, public university. Students were classified, based on cumulative grade point average and ACT/SAT scores, as low middle or high achievers. Web-based tutorials were created for each chapter and consisted of the following: 
- an explanation of the main concepts;

- relevant terminology presented in lay terms rather than technical jargon;

- demonstrations of how to solve accounting problems; and

- an invitation for learners to try to solve the problems.

The use of Web-based tutorials was not a requirement but was available for all students. The results indicated that Web-based tutorial availability was significantly associated with student performance. That is, exam scores were higher for all students (low, middle and higher achievers) who self-selected into voluntary supplemental instruction with the use of Web-based tutorials.

He, Swenson, and Lents (2012) compared student performance between lecture classes with and without the use of Web-based tutorials. The study spanned from fall 2009 through spring 2011 and included 100 students enrolled in a four-credit analytical chemistry course required of all forensic science students. Students in the experimental group attended a 75-minute lecture twice a week and participated in a 5-hour lab once a week using a Web-based tutorial. Students in the control group also attended a 75-minute lecture twice a week but without the use of a Web-based tutorial. Data collection included homework assignments and exam results. The overall results of the study indicated that the experimental group outperformed those in the control group, thus, the authors concluded that the use of a Web-based tutorial had a positive impact on student performance.

\section{No Significant Difference Found in Student Performance}

The most significant results from research in this area indicate that outcomes achieved using Web-based tutorials are at least the same as for those in traditional face-to-face settings. For instance, Merino and Abel (2003) compared test scores of those students using Web-based tutorials to those who received traditional lectures on the same topic. The study participants included 150, fourth- and fifth-year undergraduate engineering students. The authors confirmed their hypothesis that both approaches would be satisfactory instructional methods that would yield similar results; hence, the findings indicated that there was no statistical difference in student performance between the Web-based tutorial group and the traditional lecture group.

Davis, Crabb, Rogers, Zamora, and Khan (2008) assessed student performance gains in an undergraduate medical education program at the University of Birmingham, UK involving 179 first year medical students. The researchers conducted a concealed, randomized controlled trial of a Web-based session, integrated with lecture videos versus a lecture-based teaching session of similar structure and duration. Result outcomes showed that participants' improvement in knowledge in the Web-based group was equivalent to the lecture-based group (gain in score $0.8\{\mathrm{SD}=3.2\}$ versus $1.3\{\mathrm{SD}=24\} ; \mathrm{p}=0.24)$; hence, the researchers conclude that Web-based tutorials and typical lecture sessions have similar educational gains.

Margolis, Gerdiagin, Koenig, and Sanders (2009) compared the effectiveness of Web-based tutorials to traditional lectures. The participants (48) completed a pre-quiz before instruction and a post-quiz at its conclusion. The results show there was no difference in the effectiveness of the two instructional methods on the basis of post-quiz scores (Web-based group $=75.58$, face-toface group $=73.27, p=0.436$ ). Change in scores from pre to post also showed no significant difference between the two groups, $\mathrm{p}=0.375$ ). The authors concluded that Web-based tutorials can be an effective tool for student learning.

\section{Greater Student Performance with Face-to-Face Lectures}

While there have been substantial amounts of research comparing Web-based tutorials to traditional face-to-face lectures, few have found not so promising results in student performance for 
Web-based tutorials beginning with Cracolice and Abraham (1996) and Sweeney and Ingram (2001) who agreed that while Web-based tutorials are more innovative and enjoyable, students assigned to traditional lecture environments, in most instances, outperformed their counterparts assigned to the Web-based environment. Likewise, Debord and colleagues (2004) found similar results as student performance in introductory psychology classes was not improved by making Web-based tutorials available versus face-to-face lectures.

Elicker, O'Malley, and Williams (2008) compared student learning outcomes using two different instructional strategies in an introductory psychology class. Both groups received face-to-face lecture, however, chat room and e-mail the instructor features were added to a basic WebCT site for the experimental group while the control group utilized the publisher provided Web-based tutorial modules. The course instructor noted that while students in the basic control site indicated they used the Web-based tutorial modules for homework and test preparation significantly more frequently than the students in the experimental lecture/WebCT sections, the control students performed less well in the scores on the three dependent variables of tests, homework assignments, and a paper. The authors inferred from their research that "web-based instructional tools, including tutorials, made available to students were ineffective in increasing their performance compared to the easier communication with the instructor provided by the experimental WebCT site" (p. 128).

Peroz, Beuche and Peroz (2009) compared the academic performance of those students using a Web-based, self-study tutorial with those who attended traditional lectures. The study participants included 85 pre-clinical dental students who were randomly divided into the computer assisted learning group and the lecture group. The study results were as follows: (a) the groups had similar results in the pretest; (b) the results of the first post-test were significantly better for the lecture group; and (c) the results of the second post-test were not significantly different between both groups. The researchers reported that the traditional lectures received better educational and enjoyment value when compared to the Web-based, self-study tutorial. To this end, Farley, Jain, and Thomson (2011) suggests that static Web-based tutorials are not seen to be as useful in the learning process as face-to-face learning.

\section{Methodology}

The current study was conducted at Tennessee State University (TSU), a comprehensive, urban, coeducational, land-grant university located in Nashville. A constituent institution of the Tennessee Board of Regents, TSU was founded in 1912 and currently serves a growing student population of approximately 8,800 .

The current study encompasses students from the College of Business at Tennessee State University, a program that is internationally accredited through the Association to Advance Collegiate Schools of Business (AACSB, International). The College boasts an undergraduate and graduate student population of 943 of which $84 \%$ are African American, 11\% are White, 2\% Asian, 1\% Hispanic, and $2 \%$ other races. Additionally, the majority are traditional $(67 \%)$ versus nontraditional (33\%) students, with 53\% male and $47 \%$ female.

A casual-comparative design was chosen for this study to examine the effects of instructional delivery on student performance in a business communications course with specific emphasis on the grammar and mechanics unit of study. The study spanned 4 years, beginning fall 2008 through spring 2012. Participants included 375 declared business majors who were self-enrolled in various sections of the Business Communications course during the study. The course is a requisite for all business majors toward gradation with further requirements to maintain at least a grade point average of 2.0 in all core courses, the equivalent of a " $C$ " average. All course sections used 
in this study were run consecutively and were facilitated by the same professor who holds a doctorate in Instructional Systems Design.

In order to test the relative efficacy of delivering instruction via the Web, we created two versions of a unit of study involving grammar and mechanics, one to be delivered principally with the use of Web-based tutorials and one principally by lectures. The two versions were as identical in all respects as we could make them except for the delivery format.

The Web version introduced students to a self-teaching tutorial that reviewed basic grammar and mechanics for study years 1 and 2 . The digitized, interactive tutorial consisted of two components. The first component, Your Personal Language Trainer, provided instructional content covering (a) nouns and pronouns, (b) verbs, adjectives and adverbs, (c) prepositions, (d) commas, semicolons and colons, (e) apostrophes and other punctuation, (f) capitalization and number usage along with hundreds of sentence reinforcement exercises with immediate feedback and explanations to maximize comprehension and retention. In the second component, students were required to complete a three-step trainer workout, as identified below, that provided rules plus exercises to reinforce learning.

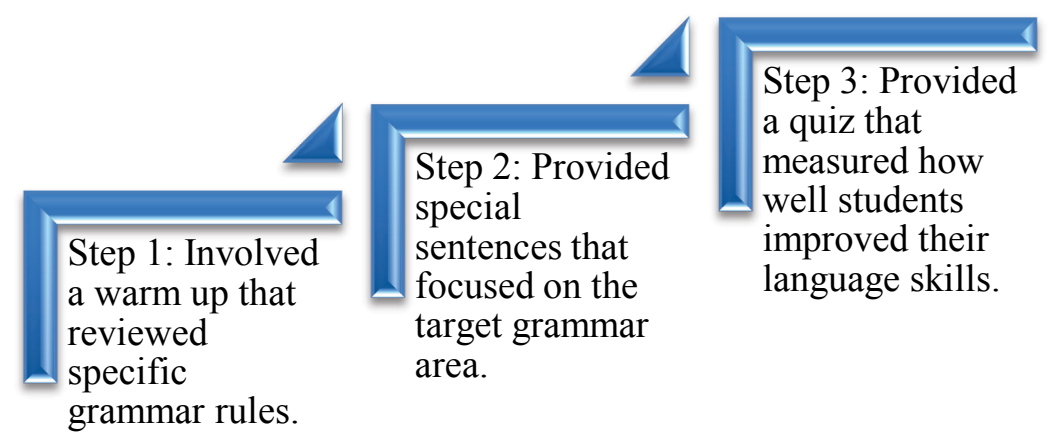

Administered during study years 3 and 4, the lecture version for the unit of study consisted of five 90-minute face-to-face lectures supplemented with multimedia PowerPoint presentations. For reading, the Web-based modules were printed out (minus, of course, the interactive simulations and exercises) and distributed to the students. Since the Web-based version involved simulations and exercises not included in the readings passed out to lecture students, extra assignments and traditional exercises approximating those given interactively online were given out to lecture students. Additionally, a different but comparable version of the Web-based tutorial quizzes was also given to the lecture students.

Students were given credit for completing the Web-based tutorial and the face-to-face exercises and quizzes. All students took identical online pre-test (administered at the start of each course), post-test mid-term (administered during mid-term week 8), and post-test final (administered at the end of the course during week 16).

\section{Results and Data Analysis}

The performance of 375 students, who were self-enrolled in various sections of the business communications course, was analyzed for comparison data using Web-based tutorial and face-toface lecture methods of instruction. The data was analyzed using descriptive and inferential statistics for which Statistical Package for Social Sciences (SPSS) was used with the significance level set at $\mathrm{a}=0.05$.

Data analysis in this study consisted of two phases. In Phase 1, frequencies were used to provide quantitative summaries of grades and scores by method of instruction. 
Within one week of the start of the semester, a pre-test was administered to all study participants. The pre-test examined some of the general principles assumed to be covered in a high school course. The overall pre-test grades, as presented in figure 1, shows that the majority of the students $(67.6 \%)$ fell below passing with scores 59 and lower, $23 \%$ earned scores ranging from 60 $69,8.5 \%$ earned scores between $70-79$, and $.9 \%$ achieved scores between $80-89$. The predominance of low scores indicated that students did need a review of grammar and mechanics.

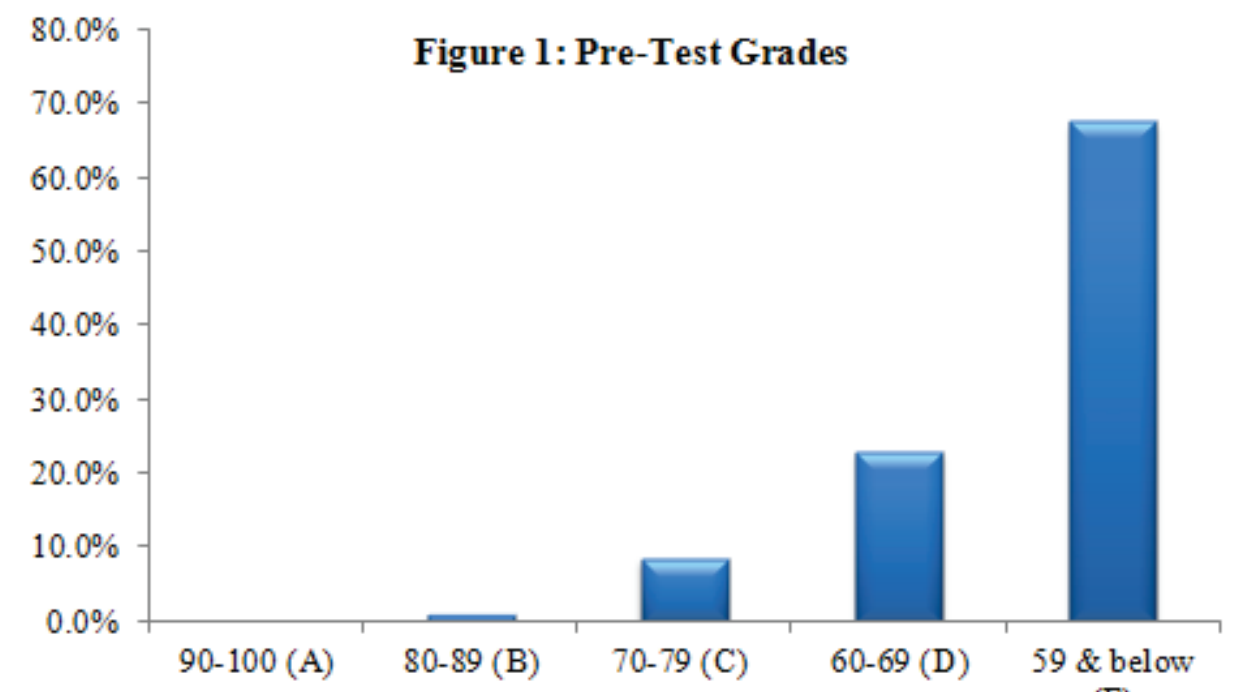

(F)

A one-way frequency table was computed to determine the rate of recurrence for each pre-test score, revealing that 34 students earned a score of $50 \%$, 32 students earned $52 \%$, and 28 students earned 58\% while only 1 student earned the highest score of $86 \%$ (see Table 1).

\begin{tabular}{|c|c|c|c|c|c|}
\hline & & \multicolumn{4}{|c|}{ Table 1: Pre-Test Frequency Count } \\
\hline & & Frequency & Percent & Valid Percent & $\begin{array}{c}\text { Cumulative } \\
\text { Percent }\end{array}$ \\
\hline \multirow[t]{17}{*}{ Valid } & 3 & 1 & .3 & .3 & .3 \\
\hline & 26 & 1 & .3 & .3 & .6 \\
\hline & 28 & 2 & .5 & .6 & 1.1 \\
\hline & 30 & 1 & .3 & .3 & 1.4 \\
\hline & 32 & 1 & .3 & .3 & 1.7 \\
\hline & 34 & 2 & .5 & .6 & 2.3 \\
\hline & 36 & 2 & .5 & .6 & 2.8 \\
\hline & 38 & 6 & 1.6 & 1.7 & 4.5 \\
\hline & 40 & 18 & 4.8 & 5.1 & 9.7 \\
\hline & 42 & 10 & 2.7 & 2.8 & 12.5 \\
\hline & 44 & 14 & 3.7 & 4.0 & 16.5 \\
\hline & 46 & 15 & 4.0 & 4.3 & 20.7 \\
\hline & 48 & 22 & 5.9 & 6.3 & 27.0 \\
\hline & 50 & 34 & 9.1 & 9.7 & 36.6 \\
\hline & 52 & 32 & 8.5 & 9.1 & 45.7 \\
\hline & 54 & 24 & 6.4 & 6.8 & 52.6 \\
\hline & 56 & 26 & 6.9 & 7.4 & 59.9 \\
\hline
\end{tabular}




\begin{tabular}{|c|c|c|c|c|c|}
\hline \multicolumn{6}{|c|}{ Table 1: Pre-Test Frequency Count } \\
\hline & & Frequency & Percent & Valid Percent & $\begin{array}{c}\text { Cumulative } \\
\text { Percent }\end{array}$ \\
\hline & 58 & 28 & 7.5 & 8.0 & 67.9 \\
\hline & 60 & 16 & 4.3 & 4.5 & 72.4 \\
\hline & 62 & 22 & 5.9 & 6.3 & 78.7 \\
\hline & 64 & 18 & 4.8 & 5.1 & 83.8 \\
\hline & 66 & 9 & 2.4 & 2.6 & 86.4 \\
\hline & 68 & 15 & 4.0 & 4.3 & 90.6 \\
\hline & 70 & 10 & 2.7 & 2.8 & 93.5 \\
\hline & 72 & 8 & 2.1 & 2.3 & 95.7 \\
\hline & 74 & 4 & 1.1 & 1.1 & 96.9 \\
\hline & 76 & 4 & 1.1 & 1.1 & 98.0 \\
\hline & 78 & 4 & 1.1 & 1.1 & 99.1 \\
\hline & 80 & 1 & .3 & .3 & 99.4 \\
\hline & 84 & 1 & .3 & .3 & 99.7 \\
\hline & 86 & 1 & .3 & .3 & 100.0 \\
\hline & Total & 352 & 93.9 & 100.0 & \\
\hline Missing & System & 23 & 6.1 & & \\
\hline Total & & 375 & 100.0 & & \\
\hline
\end{tabular}

Grades for the pre-test, as represented in Table 2, show that more than half of the students $(68.3 \%)$ earned grades below the required level in the Web-based tutorial format. Additionally, $11.7 \%$ earned grades between $70-79$ and $20.0 \%$ earned between $60-69$. Likewise, in the face-toface format a significant percentage of students fell below acceptable levels $(66.9 \%)$ while only $1.7 \%$ earned between $80-89,5.2 \%$ earned between $70-79$, and $26.2 \%$ earned between $60-69$. The low scores indicated that students did need a review of grammar and mechanics in both the Webbased tutorial and face-to-face lecture formats.

\begin{tabular}{|c|c|c|c|c|c|}
\hline \multicolumn{6}{|c|}{ Table 2: Pre-Test Grades } \\
\hline & & \multicolumn{4}{|c|}{ Treatment } \\
\hline & & \multicolumn{2}{|c|}{ Web-based Tutorial } & \multicolumn{2}{|c|}{ Face-to-Face Lecture } \\
\hline & & Count & Col \% & Count & Col \% \\
\hline \multirow{4}{*}{$\begin{array}{l}\text { Pre- } \\
\text { Test } \\
\text { Grades }\end{array}$} & $80-89(B)$ & & & 3 & $1.7 \%$ \\
\hline & $70-79(\mathrm{C})$ & 21 & $11.7 \%$ & 9 & $5.2 \%$ \\
\hline & $60-69$ (D) & 36 & $20.0 \%$ & 45 & $26.2 \%$ \\
\hline & $\begin{array}{l}59 \text { \& below } \\
\text { (F) }\end{array}$ & 123 & $68.3 \%$ & 115 & $66.9 \%$ \\
\hline
\end{tabular}

Overall performance for the post-test mid-term grades, as illustrated in figure 2, reveals that the majority of the students $(56.2 \%)$ fell below passing while only $2.1 \%$ earned scores between 80 $89,13.7 \%$ earned scores between $70-79$ and $28.0 \%$ earned scores between $60-69 \%$. The low scores at mid-term can be attributed to the low number of students who (a) completed the Webbased tutorial or (b) exercised test preparation subsequent face-to-face lectures. 


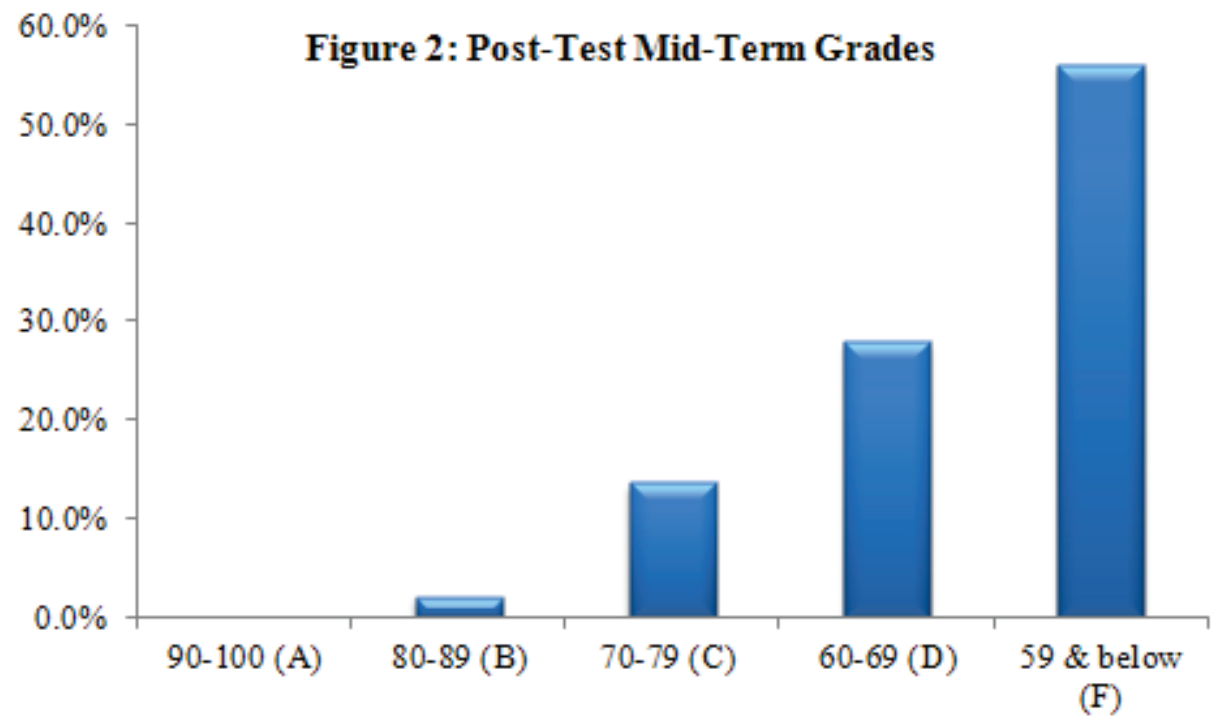

Frequencies were used to obtain counts for post-test mid-term scores as exhibited in Table 3.

Similarly to the pre-test, 39 students earned 58\%, 29 students earned 54\%, and 26 students earned $62 \%$ while only 1 student earned the highest score of $84 \%$.

\begin{tabular}{|c|c|c|c|c|c|}
\hline \multicolumn{6}{|c|}{ Table 3: Post-Test Mid-Term Frequency Count } \\
\hline & & Frequency & Percent & Valid Percent & $\begin{array}{c}\text { Cumulative } \\
\text { Percent }\end{array}$ \\
\hline \multirow[t]{23}{*}{ Valid } & 24 & 1 & .3 & .3 & .3 \\
\hline & 27 & 1 & .3 & .3 & .6 \\
\hline & 38 & 2 & .5 & .6 & 1.2 \\
\hline & 40 & 8 & 2.1 & 2.4 & 3.7 \\
\hline & 42 & 7 & 1.9 & 2.1 & 5.8 \\
\hline & 44 & 11 & 2.9 & 3.4 & 9.1 \\
\hline & 46 & 17 & 4.5 & 5.2 & 14.3 \\
\hline & 48 & 14 & 3.7 & 4.3 & 18.6 \\
\hline & 50 & 15 & 4.0 & 4.6 & 23.2 \\
\hline & 52 & 19 & 5.1 & 5.8 & 29.0 \\
\hline & 54 & 29 & 7.7 & 8.8 & 37.8 \\
\hline & 56 & 23 & 6.1 & 7.0 & 44.8 \\
\hline & 58 & 39 & 10.4 & 11.9 & 56.7 \\
\hline & 60 & 24 & 6.4 & 7.3 & 64.0 \\
\hline & 62 & 26 & 6.9 & 7.9 & 72.0 \\
\hline & 64 & 11 & 2.9 & 3.4 & 75.3 \\
\hline & 66 & 15 & 4.0 & 4.6 & 79.9 \\
\hline & 68 & 15 & 4.0 & 4.6 & 84.5 \\
\hline & 70 & 12 & 3.2 & 3.7 & 88.1 \\
\hline & 72 & 12 & 3.2 & 3.7 & 91.8 \\
\hline & 74 & 11 & 2.9 & 3.4 & 95.1 \\
\hline & 76 & 6 & 1.6 & 1.8 & 97.0 \\
\hline & 78 & 3 & .8 & .9 & 97.9 \\
\hline
\end{tabular}




\begin{tabular}{|c|c|c|c|c|c|}
\hline \multicolumn{6}{|c|}{ Table 3: Post-Test Mid-Term Frequency Count } \\
\hline & & Frequency & Percent & Valid Percent & $\begin{array}{c}\text { Cumulative } \\
\text { Percent }\end{array}$ \\
\hline & 80 & 3 & .8 & .9 & 98.8 \\
\hline & 82 & 3 & .8 & .9 & 99.7 \\
\hline & 84 & 1 & .3 & .3 & 100.0 \\
\hline & Total & 328 & 87.5 & 100.0 & \\
\hline Missing & System & 47 & 12.5 & & \\
\hline Total & & 375 & 100.0 & & \\
\hline
\end{tabular}

The post-test mid-term grades, as displayed in table 4 , shows that $1.1 \%$ earned scores between $80-89,11.5 \%$ earned between $70-79,27.6 \%$ earned between $60-69$ while the majority of the students $(59.8 \%)$ earned scores below passing in the Web-based tutorial format. Comparable percentages were reported for the face-to-face lecture format with $3.2 \%$ earning between $80-89$, $16.1 \%$ between $70-79,28.4 \%$ between $60-69$, and the majority of students $(52.3 \%)$ falling below passing.

\begin{tabular}{|c|c|c|c|c|c|}
\hline & & \multicolumn{4}{|c|}{ Treatment } \\
\hline & & \multicolumn{2}{|c|}{ Web-based Tutorial } & \multicolumn{2}{|c|}{ In-class Lecture } \\
\hline & & Count & Col \% & Count & Col \% \\
\hline \multirow{4}{*}{$\begin{array}{l}\text { Post- } \\
\text { Test } \\
\text { Mid- } \\
\text { Term } \\
\text { Grades }\end{array}$} & $80-89(B)$ & 2 & $1.1 \%$ & 5 & $3.2 \%$ \\
\hline & $70-79(\mathrm{C})$ & 20 & $11.5 \%$ & 25 & $16.1 \%$ \\
\hline & 60-69 (D) & 48 & $27.6 \%$ & 44 & $28.4 \%$ \\
\hline & $\begin{array}{l}59 \text { \& below } \\
(F)\end{array}$ & 104 & $59.8 \%$ & 81 & $52.3 \%$ \\
\hline
\end{tabular}

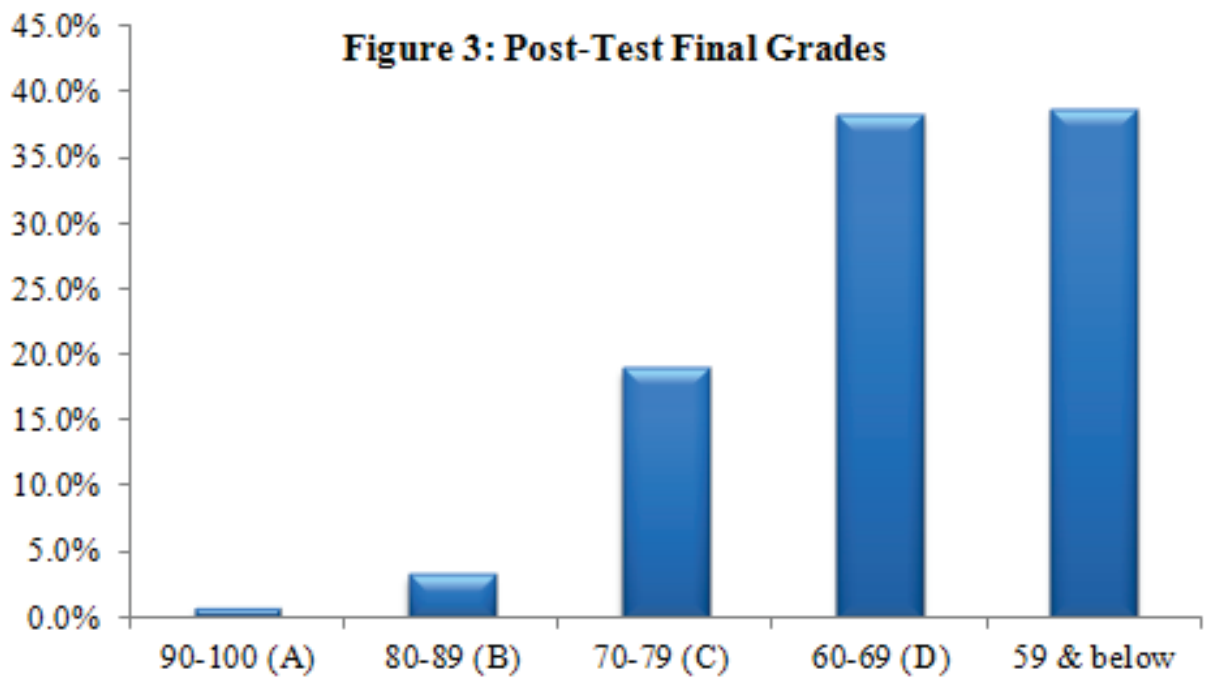

(F) 
The overall post-test final grades as illustrated in Figure 3, shows a slight improvement from the pre-test and post-test mid-term grades with .7\% earning scores between $90-100,3.3 \%$ earning between $80-89,19.0 \%$ earning between $70-79,38.3 \%$ earning between $60-69$, and $38.7 \%$ of the sample population falling below passing ( 59 and below).

Frequency Table 5 provides the rate of occurrence for post-test final scores exposing a high rate of low marks with 26 students scoring $62 \%$ and $66 \%$, uniformly. Quite the reverse was found at the other end of the grading scale revealing 1 student scoring $94 \%, 90 \%$, and $86 \%$, uniformly.

\begin{tabular}{|l|r|r|r|r|}
\hline \multicolumn{5}{|c|}{ Table 5: Post-Test Final Frequency Count } \\
\hline \\
\hline
\end{tabular}

The post-test final grades, as displayed in table 6 , shows that the students in the Web-based tutorial format performed slightly better than those in the traditional face-to-face lectures with $1.2 \%$ earning scores between $90-100,3.1 \%$ earning between $80-89,21.0 \%$ earning between $70-79$, 
$36.4 \%$ earning between $60-69$, and $38.3 \%$ falling below passing (59 and below). In the lecture series, while there were no scores earned between $90-100,3.6 \%$ earned scores between $80-89$, $16.7 \%$ earned between $70-79,40.6 \%$ earned between $60-69$ and $39.1 \%$ failed the final grammar and mechanics test.

\begin{tabular}{|c|c|c|c|c|c|}
\hline \multicolumn{6}{|c|}{ Table 6: Post-Test Final Grades } \\
\hline & & \multicolumn{4}{|c|}{$\begin{array}{ll}\text { Treatment } \\
\text { The }\end{array}$} \\
\hline & & \multicolumn{2}{|c|}{ Web-based Tutorial } & \multicolumn{2}{|c|}{ In-class Lecture } \\
\hline & & Count & Col \% & Count & Col \% \\
\hline \multirow{5}{*}{$\begin{array}{l}\text { Post- } \\
\text { Test } \\
\text { Final } \\
\text { Grades }\end{array}$} & $90-100(A)$ & 2 & $1.2 \%$ & & \\
\hline & 80-89 (B) & 5 & $3.1 \%$ & 5 & $3.6 \%$ \\
\hline & $70-79$ (C) & 34 & $21.0 \%$ & 23 & $16.7 \%$ \\
\hline & $60-69(\mathrm{D})$ & 59 & $36.4 \%$ & 56 & $40.6 \%$ \\
\hline & $\begin{array}{l}59 \text { \& below } \\
(\mathrm{F})\end{array}$ & 62 & $38.3 \%$ & 54 & $39.1 \%$ \\
\hline
\end{tabular}

In the second phase of the data analysis, a series of independent samples t-tests were run to determine if a significant difference exist in student performance between those using Web-based tutorials and those attending the face-to-face lectures.

First, the question of interest is whether the mean pre-test score for the Web-based tutorial group differed significantly from the mean pre-test score of the face-to-face lecture group, a test used in both formats to determine students' perquisite knowledge of grammar and mechanics. To answer this question, an independent samples t-test was performed and the output from the t-test is presented in tables 7 and 7.1. The results suggest that the pre-test scores did not differ significantly between the two groups. That is, the Web-based tutorial group and the face-to-face lecture group did not differ significant in their performance on the grammar and mechanics pre-test $(t=.202$, $\mathrm{p}>.05$ ). It can be concluded therefore that the groups were similar in their internal expertise and understanding of grammar and mechanics before the treatment (Web-based tutorial and face-toface lecture) was administered.

\begin{tabular}{|l|l|l|l|l|r|}
\hline & \multicolumn{5}{|c|}{ Table 7: Pre-Test Grades Group Statistics } \\
\hline \multirow{2}{*}{ Pre-Test } & Treatment & N & Mean & Std. Deviation & $\begin{array}{c}\text { Std. Error } \\
\text { Mean }\end{array}$ \\
\cline { 2 - 7 } & Web-based Tutorial & 180 & 1.43 & .694 & .052 \\
\cline { 2 - 7 } & Face-to-Face Lecture & 172 & 1.42 & .675 & .051 \\
\hline
\end{tabular}

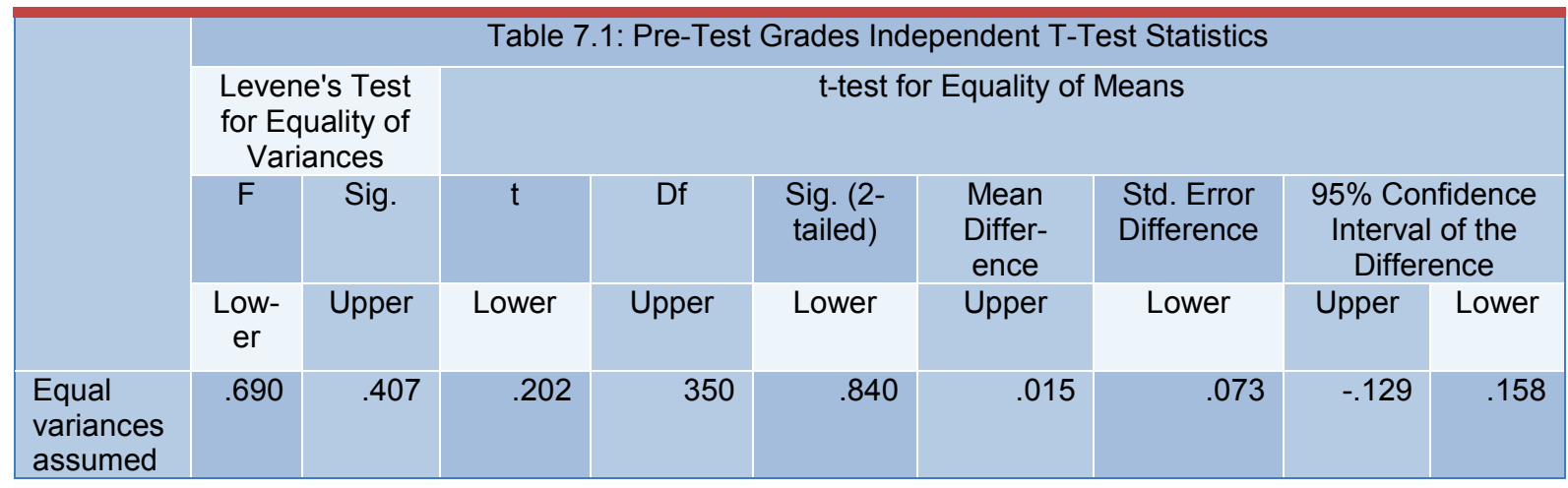




\begin{tabular}{|c|c|c|c|c|c|c|c|}
\hline $\begin{array}{l}\text { Equal } \\
\text { variances } \\
\text { not as- } \\
\text { sumed }\end{array}$ & .202 & 349.892 & .840 & .015 & .073 & -.129 & 158 \\
\hline
\end{tabular}

Secondly, the independent samples t-test was used to test the hypothesis that the difference between the means of the post-test mid-term grades for the Web-based tutorial and the face-to-face lecture groups is equal to 0 (this hypothesis is therefore referred to as the null hypothesis). Because the standard deviations for the two groups are similar (.742 and .854) as reported in table 8, we used the "equal variances assumed" test. The results indicate (see table 8.1) that there is no statistically significant difference between the post-test mid-term grades for the Web-based tutorial and the face-to-face lecture groups $(\mathrm{t}=-1.852, \mathrm{p}=.065)$. That is, the two groups did not differ significantly in their performance on the post-test mid-term, therefore the null is accepted.

\begin{tabular}{|l|l|l|r|r|r|}
\hline \multicolumn{7}{|c|}{ Table 8: Post-Test Mid-Term Grades Group Statistics } \\
\hline & Treatment & $\mathrm{N}$ & \multicolumn{1}{c|}{ Mean } & Std. Deviation & $\begin{array}{c}\text { Std. Error } \\
\text { Mean }\end{array}$ \\
\hline $\begin{array}{l}\text { Post-Test } \\
\text { Mid-Term }\end{array}$ & Web-based Tutorial & 174 & 1.54 & .742 & .056 \\
\cline { 2 - 6 } & Face-to-Face Lecture & 155 & 1.70 & .854 & .069 \\
\hline
\end{tabular}

\begin{tabular}{|c|c|c|c|c|c|c|c|c|c|}
\hline & \multicolumn{9}{|c|}{ Table 8.1: Post-Test Mid-Term Grades Independent T-Test Statistics } \\
\hline & \multicolumn{2}{|c|}{$\begin{array}{l}\text { Levene's Test } \\
\text { for Equality of } \\
\text { Variances }\end{array}$} & \multicolumn{7}{|c|}{ t-test for Equality of Means } \\
\hline & \multirow{2}{*}{$\begin{array}{l}\mathrm{F} \\
\begin{array}{c}\text { Low- } \\
\text { er }\end{array}\end{array}$} & \multirow{2}{*}{$\begin{array}{l}\text { Sig. } \\
\text { Upper }\end{array}$} & \multirow{2}{*}{$\begin{array}{c}\mathrm{t} \\
\text { Lower }\end{array}$} & \multirow{2}{*}{$\begin{array}{c}\text { Df } \\
\text { Upper }\end{array}$} & \multirow{2}{*}{$\begin{array}{l}\text { Sig. (2- } \\
\text { tailed) } \\
\text { Lower }\end{array}$} & \multirow{2}{*}{$\begin{array}{l}\text { Mean } \\
\text { Differ- } \\
\text { ence } \\
\text { Upper }\end{array}$} & \multirow{2}{*}{$\begin{array}{c}\text { Std. Error } \\
\text { Difference } \\
\text { Lower }\end{array}$} & \multicolumn{2}{|c|}{$\begin{array}{l}95 \% \text { Confidence } \\
\text { Interval of the } \\
\text { Difference }\end{array}$} \\
\hline & & & & & & & & Upper & Lower \\
\hline $\begin{array}{l}\text { Equal } \\
\text { variances } \\
\text { assumed }\end{array}$ & $\begin{array}{r}4.15 \\
9\end{array}$ & .042 & -1.852 & 327 & .065 & -.163 & .088 & -.336 & .010 \\
\hline $\begin{array}{l}\text { Equal } \\
\text { variances } \\
\text { not as- } \\
\text { sumed }\end{array}$ & & & -1.837 & 307.085 & .067 & -.163 & .089 & -.339 & .012 \\
\hline
\end{tabular}

Finally, the third independent samples t-test was run to test the hypothesis for the post-test final grades of the Web-based tutorial and the face-to-face lecture groups. Because the standard deviations for the two groups are similar (.909 and .827) as reported in table 9, we used the "equal variances assumed" tests. Comparably to the mid-term, the post-test final means were statistically indistinguishable across groups and although the Web-based tutorial group ( $\mathrm{M}=1.93)$ outperformed the students in the face-to-face lecture sections $(\mathrm{M}=1.85)$, the differences were not significant at $p=.440$. These results, as reported in table 9.1 , indicate that there is no statistically significant difference between student performance on the post-test final and the method of delivery, therefore, we accept the null hypothesis.

\begin{tabular}{|l|l|l|l|l|c|}
\hline \multicolumn{5}{|c|}{ Table 9: Post-Test Final Grades Group Statistics } \\
& Treatment & N & \multicolumn{1}{c|}{ Mean } & Std. Deviation & $\begin{array}{c}\text { Std. Error } \\
\text { Mean }\end{array}$ \\
\hline $\begin{array}{l}\text { Post-Test } \\
\text { Final }\end{array}$ & Web-based Tutorial & 162 & 1.93 & .909 & .071 \\
\cline { 2 - 6 } & Face-to-Face Lecture & 138 & 1.85 & .827 & .070 \\
\hline
\end{tabular}




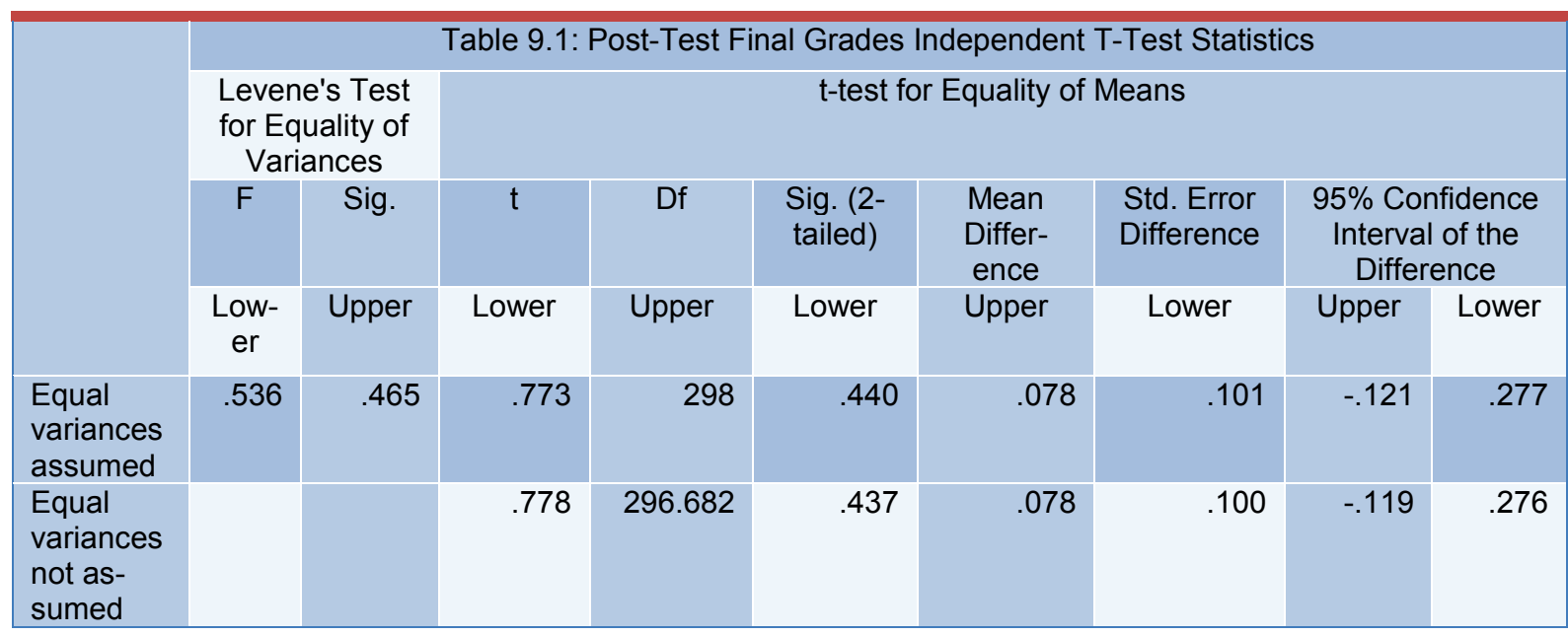

\section{Additional Analysis of the Data}

This study is a randomized comparative analysis on knowledge acquisition and knowledge retention. The influence of different content in the Web-based tutorials and the lecture presentations were reduced as both presentation materials were developed by the authors of the adopted textbook for the course. Additionally, the assessment used was provided as a supplement by the textbook authors and was deemed suitable to evaluate knowledge acquisition and knowledge retention.

The dominant question of interest in this study is whether student performance varies significantly depending on the method of delivery for instruction. In summary, the independent samples ttest presents the mean percent for each group on the pre-test, post-test mid-term, and post-test final exam scores.

The results of the t-test for the pre-test exam scores can be used to infer that the means of the corresponding population distribution did not differ significantly between the students enrolled in the Web-based tutorial sections and those enrolled in the face-to-face sections; thus, students across groups showed evidence of similar levels of perquisite knowledge of grammar and mechanics. The frequency table 1 shows that the majority of scores were concentrated in the 50-68\% range while only 3 students earned passing scores between $80-86 \%$. There are two factors to consider for interpretation of pre-test scores: (1) the results mirror student ACT/SAT scores which reveal deficiencies in writing; and (2) the results reflect students' level of motivation to perform well on a pre-test that would not be included in their final grade average.

Given the results of the t-test for the post-test mid-term and final exams, no statistically significant difference exist between student performance and the method of delivery for instruction; yet, in general, students in the face-to-face lecture sections outperformed those in the Web-based tutorial sections on the post-test mid-term exam while the opposite holds true for the post-test final exam.

Differences in scores from pre-test and post-test mid-term reveal improvement in student performance for both the Web-based tutorial group and the face-to-face lecture group. However, additional t-tests (paired samples) were performed to investigate whether the treatment (i.e., Webbased tutorials and face-to-face lectures) had an influence on the differences in scores. The test revealed that the true mean lies between -.250 and -.094 with a $95 \%$ probability. The t-statistic denotes a significant increase in the post-test mid-term grades occurred $(t=-4.35, p=.000)$ when compared to the pre-test grades within groups. Likewise, differences in scores from post-test midterm and post-test final reveal improvement in student performance for both groups. The test re- 
vealed that the true mean lies between -.382 and -.197 with a $95 \%$ probability. The $t$ statistic denotes a significant increase in the post-test final grades occurred $(\mathrm{t}=-6.178, \mathrm{p}=.000)$ when compared to the post-test mid-term grades within groups.

\section{Study Limitations}

In interpreting the results, it is important to recognize the limitations of the present study. While this study provides research on a population that is underrepresented in the literature, it also gives way to the first limitation in focusing solely on participants attending a minority-serving institution with no comparative data from a majority-serving institution. Additionally, conducting the analyses across a number of institutions would confirm the universal nature or otherwise of these findings. Secondly, incorporating qualitative analyses could improve our understanding of student performance; in particular, it could help us understand the level of student involvement and participation in the learning process.

As with the early research for which this study derived (Guy and Lownes-Jackson, 2012), the third limitation pertains to missing data that was excluded from the analysis. The differences in the frequency count for exam completions of the pre-test and post-tests scores were due to students enrolling in the course after the pre-test was administered and students withdrawing from the course after mid-term and before the final exam. Missing data can be problematic because the means of the larger study participants is estimated with less error than the means of the smaller study participants. Thus, the missing data in this study is classified as "missing at random" because of the probability that missing pretest scores is unrelated to the value of other tests scores. Finally, the course used for this study was business related which addresses the fourth limitation that frames the assumption not all disciplines have courses that are compatible with the use of Web-based tutorials.

\section{Conclusion}

Web-based tutorials are a rapidly growing educational use of the Internet. The current study recognizes Web-based tutorials as a viable option for learning by citing studies in which students using Web-based tutorials achieved as well or better as those learning in the lecture format (Alavi, 1994; Beerman, 1996; Schutte, 1996; Koch and Gobell, 1999; Maki and Maki, 2000; Andrewartha and Wilmont, 2001; Scheines, et al., 2005; Donovan and Nakhleh, 2007; Osborn, 2010; Cheng and Swanson, 2011; Sargent, et al., 2011; He, et al., 2012).

The results of the current study mirrored those of previous works reporting a non-significant difference in student performance while concluding that Web-based tutorial is as effective as traditional face-to-face lectures (Merino and Abel, 2003; Davis, et al., 2008; Margolis, et al., 2009). Perhaps, as the data suggests, Web-based tutorials and face-to-face lectures bring students to similar knowledge levels. From the conclusions reached in this study, the education community and constituents could surmise that Web-based tutorials can replace professors or at the least, serve as a supplement to lecture. However, most researchers and educators would agree that the latter (the use of Web-based tutorials as supplement to lectures) is more indicative of things to come.

The study results raise a deeper question that is beyond the scope of this article regarding the pedagogical value of Web-based tutorials as an instructional method. While Web-based tutorials offer a variety of ways to move beyond the traditional face-to-face lecture that are of greater pedagogical value, much research is needed to determine the most valuable avenues to pursue.

\section{References}

Alavi, M. (1994). Computer-mediated collaborative learning: An empirical evaluation. MIS Quarterly, $18(2), 159$. 
Andrewartha, G., \& Wilmot, S. (2001). Can multimedia meet tertiary educational needs better than the conventional lecture? A case study. Australian Journal of Educational Technology, 17(1), 1-20.

Barnes, L., Scutter, S., \& Young, J. (2005). Using screen recording and compression software to support online learning. Innovate, 1(5), 1-5.

Bartini, M. (2008). An empirical comparison of traditional and Web-enhanced classroom. Journal of Instructional Psychology, 35, 3-11.

Beerman, K. (1996). Computer-based multimedia: New directions in teaching and learning. Journal of Nutritional Education, 28(1), 15-18.

Bonham, S., Deardorff, D., \& Beichner, R. (2003). Comparison of student performance using Web and paper-based homework in college-level physics. Journal of Research in Science Teaching, 40(10), 1050-1071.

Cheng, J. (2010). The effects of cyber technology on MBA students in Thailand. Journal of Information Systems Technology and Planning, 3(5), 51-53.

Cheng, J. \& Swanson, J. (2011). An examination of the effects of Web-based tutorials on accounting student learning outcomes. Review of Higher Education and Self-Learning, 4(10), 14-28.

Cracolice, M. \& Abraham, M. (1996). A comparison of computer-assisted instruction, semi-programmed instruction, and teaching assistant-led instruction in general chemistry. School Science and Mathematics, 96, 215-221.

Davis, J., Crabb, S., Rogers, E., Zamora, J., \& Khan, K. (2008). Computer-based teaching is a good as face to face lecture-based teaching of evidence based medicine: a randomized controlled trial. Medical Teaching, 30, 302-307.

Dawson, S. (1998). Effective tutorial teaching. Melbourne, RMIT Publishing.

DeBord, K., Arguete, M., Muhlig, J. (2004). Are computer-assisted teaching methods effective? Teaching of Psychology, 35, 65-68.

Donovan, W. \& Nakhleh, M. (2007). Student use of web-based tutorial materials and understanding of chemistry concepts. Journal of Computers in Mathematics and Science Teaching, 26(4), 291-327.

Elicker, J., O’Malley, A., \& Williams, C. (2008). Does an interactive WebCT site help students learn? Teaching of Psychology, 35, 126-131.

Farley, A., Jain, A., \& Thomson, D. (2011). Blended learning in finance: Comparing student perceptions of lectures, tutorials and online learning environments across different year levels. Economic Papers, 30(1), 99-108.

Gremler, D., Hoffman, D., Keaveney, S., \& Wright, L. (2000). Experiential learning exercises in services marketing courses. Journal of Marketing Education, 22(1), 35-44.

Guy, R. \& Lownes-Jackson, M. (2012). Assessing the effectiveness of Web-based. Interdisciplinary Journal of E-Learning and Learning Objects, 8, 15-38.

Haseman, W., Nuipolatoglu, V., \& Ramamurthy, K. (2002). An empirical investigation of the influences of the degree of interactivity on user-outcomes in a multimedia environment. Information Resources Management Journal, 15(2), 31-39.

He, Y., Swenson, S., \& Lents, N. (2012). Online video tutorials increase learning of difficult concepts in an undergraduate analytical chemistry course. Journal of Chemical Education, 89, 1128-1132.

Koch, C. \& Gobell, J. (1999). A hypertext based tutorial with links on the Web for teaching statistics and research methods. Behavior Research Methods, Instruments, \& Computers, 31, 7-13.

Lee, W., Courtney, R., \& Balassi, S. (2010). Do online homework tools improve student results in principles of microeconomics courses? The American Economic Review, 100(2), 286-296. 
Maki, W. \& Maki, R. (2000). Evaluation of a Web-based introductory psychology course: II. Contingency management to increase use of online study aids. Behavior Research Methods. Instruments \& Computers, 32, 240-245.

Maki, R. \& Maki, W. (2003). Prediction of learning and satisfaction in Web-based and lecture courses. Journal of Educational Computing Research, 28(3), 197-219.

Margolis, L., Grediagin, A., Koenig, C., \& Sanders, L. (2009). Effectiveness and acceptance of Web-based learning compared to traditional face-to-face learning for performance nutrition education. Military Medicine, 174, 1095-1099.

Merino, D. \& Abel, K. (2003). Evaluating the effectiveness of computer tutorials versus traditional lecturing in accounting topics. Journal of Engineering Education, April, 189-194.

Moallem, M. (2008). Accommodating individual differences in the design of online learning environments: A comparative study. Journal of Research on Technology in Education, 40(2), 217-235.

O'Hanlon, N. (1999). Web-based tutorials: Does course use differ from general use? Journal of Interactive Learning Research, 10, 217-228.

Oppenheimer, T. (2003). The flickering mind: The false promise of technology in the classroom and how learning can be saved. New York: Random House Publishing Group.

Osborn, D. (2010). Do print Web-based, or blackboard integrated tutorial strategies differently influence student learning in an introductory psychology class? Journal of Instructional Psychology, 31(3), $247-$ 251.

Peroz, I., Beuche, A., \& Peroz, N. (2009). Randomized controlled trial comparing lecture versus selfstudying by an online tool. Medical Teacher, 31, 508-512.

Sandman, T. (2009). Gaining insight into business telecommunications students through the assessment of learning styles. Decision Sciences Journal of Innovative Education, 7(1), 295-317.

Sargent, C., Borthick, A., \& Lederberg, A. (2011). Improving retention for principles of accounting students: Ultra-short online tutorials for motivating effort and improving performance. Issues in Accounting Education, 26(4), 657-679.

Scheines, R. Leinhardt, G., Smith, J., \& Cho, K. (2005). Replacing lecture with Web-based course materials. Journal of Educational Computing Research, 32(1), 1-26.

Schutte, J. (1996). Virtual teaching in higher education: The new intellectual super-highways or just another traffic jam? Retrieved from http://www.csun.edu/sociology/virexp.htm

Seal, K., Przasnyski, Z., \& Leon, L. (2010). How levels of interactivity in tutorials affect students' learning of modeling transportation problems in a spreadsheet. Decision Sciences Journal of Innovative Education, 8(1), 75-94.

Sikorski, J., Rich, K., Saville, B., Buskist, W., Drogan, O., \& Davis, S. (2002). Student use of introductory texts: Comparative survey findings from two universities. Teaching of Psychology, 29, 312-313.

Singh, C. \& Haileselassie, D. (2010). Developing problem-solving skills of students taking introductory physics via Web-based tutorials. Journal of College Science Teaching, 42-49.

Sweeney, J., O’Donoghue, T., \& Whitehead, C. (2004). Traditional face-to-face and Web-based tutorials: a study of university students' perspectives on the roles of tutorial participants. Teaching in Higher Education, 9(3), 311-323.

Sweeney, J. \& Ingram, D. (2001). A comparison of traditional and web-based tutorials in marketing education. Journal of Marketing Education, 23(1), 55-62.

Windschitl, M. (1998). The WWW and classroom research: What path should we take? Educational Researcher, 27(1), 28-33.

Zhang, D. (2004). Virtual mentor and the lab system - toward building an interactive, personalized, and intelligent e-learning environment. The Journal of Computer Information Systems, 44(3), 35-43. 


\section{Biographies}

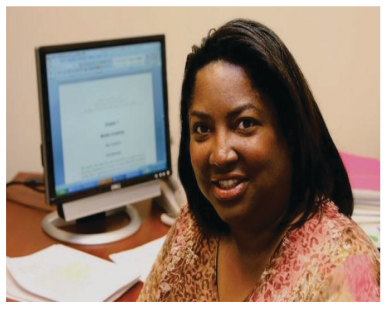

Dr. Retta Guy has an Ed.D. in Curriculum and Instruction with emphasis in Instructional Systems Design from the University of Kentucky. Currently, she is serving as Interim Associate Dean for the College of Business at Tennessee State University in Nashville. As an active author, Dr. Guy's scholarly publications include an authored book entitled "The Digitally Disinterested," two edited books entitled "The Evolution of Mobile Teaching and Learning" and "Mobile Learning: Pilot Projects and Initiatives," 6 book chapters, 30+ articles, and 10 refereed proceedings to date. Dr. Guy's intellectual interests include the use of digital technologies to augment teaching and learning, instructional design and assessment, as well as distance learning with specific emphasis in hybrid, online and mobile teaching and learning.

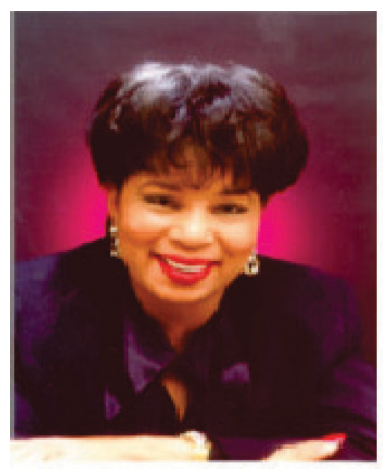

Dr. Millicent Lownes-Jackson is the Interim Provost and Executive Vice President at Tennessee State University. She is a small business specialist, author of 15 books, an entrepreneur, newspaper columnist, researcher, certified small business coach, and a tenured Professor of Management. Dr. Lownes-Jackson's educational background includes a Bachelor of Business Administration Degree from Fisk University. She also has a Master of Business Administration Degree and a Doctor of Philosophy Degree, both of which were conferred by Vanderbilt University. Dr. Lownes-Jackson has many research articles, publications and talk show appearances to her credit. She has been featured in numerous stories including articles appearing in Black Enterprise magazine, Contempora magazine, the Tennessee Tribune and the Urban Journal. 